\title{
ISLAMIC LIBERATION THEOLOGY: QUR'ANIC HERMENEUTICS FOR THE CHALLENGES OF THE MODERN AGE
}

\author{
Kaloi Abdul Rehman*
}

\begin{abstract}
This paper is both an overview of liberation theology as developed in modern Christian theology in the West and an explanation of Islamic liberation theology from a socio-economic and theological perspective, excerpted from the Qur'an and its hermeneutics. Islam has, since its inception, through the injunctions of the Qur'an and the traditions of the Prophet Muhammad, liberated human beings from all sorts of sufferings and revived their dignity from social scourges. Islam, by its initial teachings, denounced ignorance and socio-economic injustice and then promoted knowledge, wisdom, justice, equality, respect, and fairness. All such teachings regarding liberation from all sorts of socio-economic sufferings and oppressions are clearly mentioned and their solution described in the Qur'an and in the traditions of the Prophet Muhammad. Classical Islamic theology in only its metaphysical form has been criticised by progressive Muslims because it does not imply human liberation in worldly life. This paper also discusses liberation theology in Islam through its sociological, ontological, epistemological and axiological perspectives and as many have also been propagated with respect to Islamisation. It also addresses the modern issues and challenges of cultural globalisation or the Westernisation of science in view of new dialectical theology (kalam e jadid) and proposes de-Westernisation of academic culture as an integral part of Muslim's liberation in modern age.
\end{abstract}

Keywords: Islamic liberation theology, Qur'anic hermeneutics, challenges of modern Age

\section{Introduction}

The twenty first century is the age of globalisation, science and technology but many human societies are stumbling into several crises. Today, millions of people are suffering from injustice and oppression. Human beings still, undergo the stress of unemployment, poverty, starvation, malnourishment and homelessness. Refugees and marginalised people are victims thanks to war and violence brought 
about in many socio-politico-religious (in terms of religious extremism, ethnoreligious nationalism) and economic factors. People leave their homes and lands and become scattered in many neighbouring countries, working for low wages, bearing the torment of racism and discrimination. But, for just the survival of their children, they tolerate such afflictions and hope to achieve liberation from suffering and oppression.

Liberation is not only freedom or emancipation from oppression and violence, slavery and injustice, poverty and cruelty, sufferings and atrocities; it is also the overcoming of illiteracy, ignorance and unemployment, major causes of depression and crime. Further, liberation from one's ego, and the will to control and to dominate, are also appreciated in most world religions. The world's major religious traditions have a variety of notions regarding the term "liberation" but all agree that it is a fundamental need for every human being to be liberated from spiritual debauchery, economic greed, racial prejudice and cultural and political imperialism. ${ }^{1}$

\section{Liberation Theology?}

The term "liberation theology," according to the Oxford Dictionary of Religions, means "an understanding of the role of theology in moving from abstraction to praxis, in which the actual condition of the poor is the starting point." ${ }^{2}$ The Encyclopedia of Religion defines liberation theology "as critical reflection on the historical praxis of liberation in a concrete situation of oppression and discrimination." ${ }^{\prime 3}$ It is also known as a social movement within the Christian Church and a school of thought, both of which react against human suffering due to poverty and various forms of oppression. ${ }^{4}$

'Liberation theology' ${ }^{5}$ as an insurrection movement was a Christian struggle that started in Latin America during the 1960s. This movement sought to revive basic human values within the biblical sources, the teachings of Jesus and the Church. But, simultaneously, African and Asian countries were also struggling against colonial domination and other afflictions during that era. ${ }^{6}$ The term liveration theology may therefore be applied to these problems too, because as a concept it stands for the revival of the liberating notion that calls for the uplifting of human dignity, not only from socioeconomic and political oppression but also from spiritual decadence. ' 'Liberation theology' is defined as a critical reflection on the historical praxis of liberation in a concrete situation of oppression and discrimination. ${ }^{8}$ It is the continuous struggle to establish a just and fraternal society where people can live with dignity and freedom. ${ }^{9}$ Further, if explained in simple words, it means to interpret scriptures through the conditions of unprivileged people, to struggle for the betterment of the oppressed 
and marginalised class, to help the poor and liberate them from the suffering of poverty and starvation and enable them to stand with the working class. ${ }^{10}$

Liberation theology, in fact, was a religious movement that sought to liberate people from poor social conditions and injustice. It emphasises the Christian mission of bringing justice to the poor and oppressed. As part of Christian theology, liberation theology has been most frequently been associated with the Catholic Church in Latin America. However, the phenomenon of liberation theology is also referred to in many other traditions, which convey it through their religious teachings, symbols, discourse and activism. ${ }^{11}$

The actual message of liberation theology is to the plight of the oppressed, hungry, poor and marginalised. God exhorts us to struggle for human well-being, to strive for human rights and to liberate humanity from socio-economic injustice. In other words, it is a way, a discipline, an exercise that has to be practically carried out. Liberation theology, as it is connected with the Christiania tradition, stresses that the Church must advocate and help the poor and try to save them from affliction and marginalisation due to socio-political injustice, in a spiritual way and with regard to the scriptural message. ${ }^{12}$

In a broader sense, liberation theology includes an interpretation of scripture that is rooted in the everyday experience of poverty. It is an effort to improve human welfare in very basic ways. Poor people are encouraged to read the scriptures themselves so that they may know what the purpose of God is and how much hope He gives through His Scriptures to His servants. ${ }^{13}$

Liberation theology, according to Leonardo and Clodvis Boff, is a systemic structure, like an organisation that works for the betterment of every individual in society; everyone has a right to benefit from its sources and means; no one should be deprived of its benefits. ${ }^{14}$ Liberation theology is one of the most significant movements in Christian theology, dominating the intellectual horizon of theologians in universities and seminaries. It is currently among the manifestations of a worldwide movement for human emancipation. ${ }^{15}$ For Phillip Berryman (1987), liberation theology is a systematic, disciplined reflection on Christian faith and its implications. He explains that it is an interpretation of Christian faith out of the experience of the poor and an attempt to read the Bible and key Christian doctrines with the eyes of the poor. At the same time, it is an attempt to help the poor interpret their faith in a new way. He further elaborates that liberation theology focuses on Jesus' life and message; he quotes the words of Jesus (Luke 4:18-19), "He has sent me to bring glad tidings to the poor, to proclaim liberty to captives..." The poor learn to read the scripture in a way that affirms their dignity and self-worth and their right to struggle together for a more decent life. ${ }^{16}$ Therefore, liberation theology, normally associated with Christian theologians, came to see the massive poverty of the majority of people 
in Latin America as systemically supported by social institutions and radically unjust. ${ }^{17}$

\section{The Concept of Islamic Liberation Theology}

Islamic liberation theology emerged when the Qur'an started to be revealed to the Prophet Muhammad. The Qur'an, like the Bible, seeks to liberate people from all kinds of sufferings and in different ways (socioeconomic and theological). The Qur'anic commandments were an open challenge to the tribal lords of Mecca, who would oppress and dehumanise the poor. Islam, since its beginning, through the teachings and commandments of the Qur'an, denounced injustice and oppression, and condemned the prevailing social system of Mecca. With the message of the Qur'an, Islam proclaimed liberation, freedom, justice and equality, ${ }^{18}$ it was stated that all people are equal before God and there is no entity who deserves to be worshiped but He (God) (Qur'an, 2:255).

Qur'anic liberation theology is the best source and guideline for liberation from all kinds of injustice and discrimination. It accords with socio-economic balance, an equal social structure and assigns a high position to human dignity. Muslim revivalist movements also began as struggles for social, political, and economic liberation. They sought liberation from colonial oppression during the nineteenth and early twentieth centuries. Nonetheless, the dominant perception was that Muslim reformers simply wanted to defend the Islamic faith against its erosion in the wake of imperialism and cultural annihilation. ${ }^{19}$

In the modern age, injustice and discrimination against oppressed and marginalised people is taking place in almost every part of the world, especially in underdeveloped countries. International media and human rights organisations have often described Rohingyas as one of the most persecuted minorities in the world. Hundreds of thousands of people have been killed and injured in Kashmir. Communal riots and he killing of Muslims over eating beef in India is a major concern for Muslim minorities in Hindu majority areas; the plight of Palestine is also a big challenge for the Muslim world. The globe faces the challenge of ethno-religious nationalism and intolerance, notions of racial superiority, and inter- and intra-religious conflicts. Differences and clashes are indeed a big threat to world peace in the modern age. So, how to address the issues of injustice and oppression? What are God's commandments in relation to abuses in the contemporary age? How to mitigate these pressures upon the weaker parts of society? How do scriptures and theology admonish the authorities to help the poor and ease their suffering? What should be the multi-dimensional solution for world peace? 


\section{The Inception of Islamic Liberation Theology}

Jesus played the role of liberator for his people. Liberation theologians affirm that Jesus came to liberate humanity not only from spiritual decadence, but also from the bondage of material poverty and social injustice. The Prophet Muhammad liberated people from the oppression of the Meccan upper classes. He conveyed the message of God to the people, with warnings and glad tidings, for the construction of a just society that should be based on equality, fraternity and justice.

Islamic liberation theology started when the Prophet Muhammad received inspiration in the first message of revelation, which instructed him to "Read". This was a message that sought to liberate humanity from darkness, ignorance and illiteracy. It also taught awareness that God is the One who created humanity. Thus, in light of these early revelations, the Qur'an liberated humanity from ontological ignorance and stated that there is One Entity who gives life and brings human beings into existence (al-Qur'an, 96:1). From this verse, it is inferred that man should not hold any misconceptions about his creation. Such indications and instructions were also mentioned in previous divine scriptures and messages. Caesar E. Farah (1968) writes, "Muhammad had no intention of founding a new religion and did not consider his mission as superseding his predecessors, he looked upon his mission rather as serving to complete and revitalize these earlier religions and to set straight misconception associated with them." When Muhammad received revelation, it came in the form of a reformative and revolutionary message to all the people of the world, as he was given the title of mercy for all the worlds (al-Qur'an, 21:107). He delivered the message of the Qur'an, the message which was revealed to him for the reformation of society in general and of Arabia in particular. The Qur'an affirms that God sent him to deliver glad-tidings to people (al-Qur'an, 2:119). Since then, the Prophet started to preach a new version of the previous Sharia and to act upon the teachings of the Qur'an. The Prophet Muhammad worked for the liberation of the oppressed, the poor, the needy and the ignorant. In his project of liberation, he was not just a prophet, teacher and philosopher, but also an activist who sacrificed his life for justice and equality. Under his inspiration, the Arabs not only liberated themselves but in turn liberated others from oppression and subjugation. ${ }^{20}$

\section{The Socio-Economic and Religious Background of Arabia before Muhammad}

The Prophet Muhammad was born at a time when people were engaged in arrogant displays of tribal superiority. Privileges were based on unjust conditions 
and prejudices. In such circumstances, he stood up and challenged unjustified privilege and established social and moral values based upon the revealed message. He liberated people from slavery and delivered the oppressed from the dictatorship of the tribal leaders of Mecca. ${ }^{21}$ The social status of the Arabian Peninsula was baed on diverse tribal factions without any ruling system. Related families comprised a clan, while a number of clans formed a tribe. Every tribe had a hegemony in its territory. The Arabs laid great emphasis on tribal ties because they were the foundations of their power. Tribal affiliation was not just for individual identification but also for protection. The unending wars among the tribal fractions continued for long time and many deaths were claimed in those wars. The society was at risk and people were waiting for a miracle to save them from the oppression of the dominant class that had marginalised the poor and left them helpless. ${ }^{22}$

As far as religious conditions were concerned, many gods and goddesses served as the 'protectors' of individual tribes and their spirits were associated with sacred objects, for example trees, rocks, springs, and wells. Local tribal deities were feared and respected rather than loved. The focus of rituals (sacrifice, pilgrimage, prayer) and of supplication and propitiation were local shrines. Mecca possessed a central shrine of the gods, the Kaaba, a cube-shaped building that housed the 360 idols of tribal patron deities and was the site of a great annual pilgrimage and fair. ${ }^{23}$

In this environment, Muhammad was inspired by God to deliver the revealed message. The message was intended to liberate people from polytheism and superstition, and teach monotheism. It was a call to worship God in gratitude for His goodness both to each individual and to the Meccans as a whole. But the people of Mecca refused to accept the message, except for a few. Due to the opposition and rejection of the Meccans, the first ten years of Muhammad's preaching were hard. He was persecuted and threatened. Muhammad's message and aim were to bring reform to society and condemn the socioeconomic inequalities of Meccan life. He therefore presented a direct threat not just to traditional polytheistic religion, but also to the power and status of the establishment, threatening its economic, social and political interests. He condemned false contracts, usury, as well as the negligence and exploitation of orphans and widows. He defended the rights of the poor and the oppressed, declaring that the rich had a responsibility to the poor to use a portion of their wealth for their benefit. ${ }^{24}$

A truly liberating theology grew from this tradition. Islamic theology is grounded within this historical tradition, which in turn is derived from the primary foundations of the Islamic tradition-the Qur'an and the Sunnah and, more importantly, in how the core message affects the daily lives of the people in need of this theology. The importance of Islamic liberation theology is not just 
its relation to historical, religious, and cultural contexts; it provides the grounds on which the liberating elements must be developed for the welfare of the people in general..$^{25}$

\section{Criticism of Classical Islamic Theology}

Classical Islamic theology began to face the problem of free will and vis-à-vis determination only after the establishment of the powerful Umayyad Empire founded by Muawiyah, (602-680). Muawiyah and his successors established a dynastic form of rule that was against the Islamic democratic spirit. Opponents of the Umayyad however, were persecuted. To prevent further arrest, the Umayyads encouraged the dogma of pre-determination against free will. This became the subject of intense discussion in Islamic theology. Those opposing the regime supported the concept of free will. Those supporting the regime emphasised pre-determination. In Islamic theology, the two terms that were used during the Umayyad regime were invented by the Mu'tazilah: 1) 'ikhtiyar' (free-will) and, 2) Jabar (pre-determination). The followers of the former was called qadriyah, while the latter were known as Jabria. Besides these two groups, there was another sect, the Khawarij, that was in favour of free will as well as revolution. That sect was against tyrannical rulers and fighting them was the primary principle of their theology. ${ }^{26}$ Muslim theologians during the Umayyad dynasty ${ }^{27}$ only discussed theology in its metaphysical context. ${ }^{28}$

By contrast, progressive Muslim scholars ${ }^{29}$ have criticised and opposed classical Islamic theology and Muslim theologians. In fact, theology in its received form, according to progressive Muslims, does not support human liberation. It only supports the status quo; moreover, theologians who support this form of theology are partners to the status quo. The actual purpose of liberation theology is liberation from suffering. If theology is to be considered in its metaphysical form only, then liberation would take only a metaphysical, not a physical, form. The metaphysical concept of theology appears obscure and confused. The received form of theology supports the status of traditional theologians who became allies of the establishment to gain personal benefits. They supported a pre-determined fate for human beings and opposed freedom of action by man, reducing him to a mere puppet in the hands of fate. ${ }^{30}$ Thus, classical theology in its orthodoxy form was careful to steer away from the real problems of human life. This makes religion meaningless to weak and oppressed people - a view attributed to Marx, who labelled religion as the "opium of the masses." 


\section{The Qur'anic Paradigms of Liberation Theology}

The first objective of Islamic liberation theology, as has been shown by the verses of revelation, is to liberate people from ignorance, illiteracy, superstitions and polytheism. Revelation further seeks to familiarise the believers with the concept of the unity of God (96:1-5), (112: 1-4). The Qur'an liberates man from confusion and superstition, exhorting him not to take any figure, idol or stone for worship. Qur'an liberates from polytheism (21-22). Polytheism is a source of injustice and oppression. The Qur'an also liberates humanity from racism. Racism is the worst type of evil, in which people think that a particular race is superior to others. It exists in almost every society, creates social problems and hatred between social classes. The Qur'an condemns notions of racial superiority or inferiority. Instead, it teaches that all people are the children of Adam and Eve and equal before God (49:13).

The main goal of liberation theology, according to the Qur'an, is to provide financial help to the poor and liberate them from poverty (4:95). The Qur'an teaches that a Muslim must always take the side of the weak regardless of their religion and race, and asks the question, "Who among those in need would require more attention than the poor and the destitute?" (4:95). The Qur'an also protects man from subjugation. It liberates man from the tyranny of governments and rulers. The Qur'an gives rights to every individual equally so that all will be treated and judged on an equal basis, irrespective of race, colour and faith (49:130). It also admonishes believers to establish justice in all spheres of life (4: 135).

Qur'anic liberation focuses on justice, freedom and equality on the one hand, and the condemnation of exploitation of man by man, oppression, and persecution on the other. ${ }^{32}$ Asghar Ali Engineer, ${ }^{33}$ one of the most progressive and reformist faces of the Islamic world, developed the idea of Islamic liberation theology, which he retrieved from the Qur'anic teachings. He identified its core values in "key terms of the Qur'an" comprising tawhid, (oneness of God), din (religion), adal (justice), rahmah (compassion), ihsan (benevolence), and hikmah (wisdom). These key terms, to Engineer, are the main tools for constructing the platform of Islamic liberation theology. ${ }^{34}$ Other scholars take the idea of liberation theology in a very theological way, such as Maududi, whose notion of liberation theology may be found in his book, "Four Basic Qur'anic Terms." He says that the main teachings of the Qur'an consist of four theological terms that Ilah, Rabb, Deen and 'Ibadah. A Muslim, according to Maududi, cannot attain a full understanding of Islam until he/she understands all four of them. ${ }^{35}$ 


\section{The Prophet Muhammad as a Liberator}

The Prophet Muhammad liberated people from all sorts of sufferings. Through the Qur'an, he liberated people from ignorance and superstition, from polytheism and racism, from poverty, inequality, subjugation and injustice. This means that Islamic liberation theology is an all rounded affair. The Prophet Muhammad struggled on behalf of promoting Islamic injunctions against the tribal cruelties without engaging in violence. He and his companions bore the brutalities of the Meccans and continued to propagate and practice a way of life that was based upon revealed teachings. The paradigm of struggle and resistance to injustice, established by the Prophet Muhammad and his early followers, was a movement of liberation. Many Muslim movements that developed in later centuries attempted to follow this prophetic paradigm, and together these have become important sources of inspiration for many contemporary Muslim liberation struggles. ${ }^{36}$

The Prophet Muhammad was the beacon of light who announced through the Qur'an a charter of rights for women. The Qur'an, for the first time, gave them various rights: the right to be a witness, the right to marry a husband of her own choice, the right to divorce her husband without any pre-condition, the right to inherit her father's property, the right of mothers and relatives to have property, the right to have custody of children, and the right to make decisions freely. Thus, due to Muhammad's prophethood, women gained social dignity and respect. The Prophet aimed to establish justice within the socio-economic environment of Mecca; he was deeply disturbed by the conditions of women. ${ }^{37}$

Though the idea of modern liberation theology has been derived from Christian hermeneutics, we can say that all religious scriptures have a solution for liberating people from suffering. The Qur'an not only supports the oppressed and weak sections of society, but teaches lessons of equality, dignity, freedom and respect for each other. It also calls on its believers to respect and recognise the truth of other religions. The Qur'an provides the guidelines and ways to liberate people from all kinds of sufferings. God has sent the prophets to each and every community for their guidance. A universal theology of liberation is found among all religions. It is a method by which the implementation of God's rule on earth, the establishment of justice, equal rights and uplifting peoples' standard of living may be achieved. Liberation theology prioritises praxis over theory. It advocates the protection of the oppressed from the oppressors. It provides socio-political resistance against oppressors. It is a theology in real sense that aims to implement a world reality based upon respect for human dignity and the realisation justice. ${ }^{38}$ 


\section{Liberation Theology from a Sociological Perspective}

Many progressive Muslim scholars ${ }^{39}$ believe that the actual spirit of theology is not restricted to its classical or purely traditional manifestations but also has sociological relevance. In this regard, many verses of the Qur'an justify sociological theology. The Qur'an advises applying theology and theological teachings in their practical modes, i.e. in a sociological context so that those people who suffer from troubles and worries may get satisfaction and the help of Divine commandments. In this regard, Ali Shariati, an Iranian revolutionary and sociologist, focused on the sociology of religion from the Islamic perspective. He supported Iranians who were oppressed, afflicted and humiliated by the Shah. Ali Shariati encouraged people to take revolutionary steps, providing many examples and lessons from the Qur'an and examples of liberators from Islamic history. Shariati reminds us that history is filled with the struggle between haqq (truth) and taghut (falsehood), an encounter between monotheists and polytheists, a battle between the oppressed and oppressors, between the deprived and the usurpers. ${ }^{40}$

The traditional and medieval approaches to Islamic theology are different from the intellectual and rational development towards the progressive mode of Islamic hermeneutics of liberation which advocates the core Qur'anic values of equality, justice and freedom.

In developing a theology of liberation for the poor and the marginalised, modern Muslim theologians must propagate views in keeping with the spirit of the Qur'an. Islam teaches the values of equality, justice and freedom. Women's rights and gender equality are emphasised greatly in the Qur'an.

We do not discuss the Qur'anic hermeneutics among the progressive Muslim scholars like Asghar Ali Engineer, Farid Esack and Said Nursi due to limitation of space. Nevertheless, we may note that while operating in specific socio-politico and cultural contexts, they suggested progressive ways to promote justice, gender equality, liberation and religious freedom on the basis of the liberation methodology. They provided a rational and intellectual exegesis, unlike the traditional and conventional theologians, who tended to rely on traditional interpretations. In these ways, the progressive and liberative elements of the Qur'anic message have been highlighted by progressive intellectuals which focus on the challenges of modernity. 


\section{Farid Esack's Interpretation of the Qur'anic Hermeneutic of Liberation}

Farid Esack, a progressive South African Muslim, promotes the idea of the Qur'anic hermeneutic of liberation in his national setting, in order to establish a more humane and non-racist society. He also promotes the idea of a Qur'anic hermeneutics of pluralism. He believes that the Qur'an itself promotes and encourages liberation using specific hermeneutical terms. These terms are essential tools for understanding the Qur'an and its motivation in the struggle for justice and freedom. ${ }^{41}$ The key words are 'taqwa,' 'tawhid,' 'al-nas,' 'almustadafun,' 'qist' and, 'adl and jihad.' According to him, 'the first two keys, 'taqwa' and 'tawhid,' are aimed at developing the moral and doctrinal criteria with which to examine the other keys and the 'theological glasses' with which to read the Qur'an in general and, more specifically, the texts dealing with the religious Other. The second two keys, al-nas (the people) and the marginalised (al-mustadafun) define the location of interpretative activity. The last two, justice ( $a d l$ and qist) and struggle (jihad), reflect the methods and the ethos that produce and shape a contextual understanding of the word of God in an unjust society." ${ }^{42}$

Speaking about liberation during the apartheid years in South Africa, Farid Esack defines liberation theology as "one that works towards freeing religion from social, political and religious structures and ideas based on uncritical obedience and the freedom of all people from all forms of injustice and exploitation including those of race, gender, class and religion." ${ }^{43} \mathrm{He}$ claims that the Qur'an's stress on helping preferentially the mustad'af refers to someone who is oppressed or deemed weak. The mustad'afun are people of inferior social status, people who are vulnerable, marginalised and oppressed. The Qur'an also uses other terms to describe the lower and impoverished classes of society, such as aradhil, marginalised (al-Qur'an, 11:27), the poor (2:271) and the indigent (2: 83). This preferential treatment of the oppressed is, according to Esack, reflected in the particularised identification of God with the oppressed. The Qur'an also denounces the powerful and their accumulation of wealth, and exhorts the believers to treat women with equality and to free slaves. According to Esack, the most significant and relevant Qur'anic text in the South African situation encompasses verses 28: 4-8. In particular, Esack quotes this verse frequently: "And it is Our will to bestow Our grace upon the mustad'afun on the Earth". This verse shows the Qur'an's socially engaged message of liberation and empathy for the oppressed. ${ }^{44}$

Esack believes that in the Qur'anic paradigm, the nature of jihad is "struggle and praxis. It is an Islamic model of liberation. It is a struggle, an effort, an exertion to the utmost, a striving for truth and justice." The Qur'an is explicit 
in its view that theory must be followed by praxis. It lays great emphasis on orthopraxis (action, activity) and strongly suggests its importance for establishing justice and truth. ${ }^{45}$

\section{A New Dialectical Theology (Kalām Al-Jadīd)}

In the modern age, Islamic revivalism arose, faced and struggled against the challenges of nationalism, liberalism and cultural hegemony and globalisation. In particular, a main challenge has been the Westernisation of science. Liberation in Islam is freedom from all forms of subjugation and domination by 'others' including in the sphere of science and knowledge. In this regard, Muslim scholars have produced a dialectical theology that charts the way of resistance and liberation from a new wave of western attacks on Islamic science, philosophy and ethics - in other words, on the theory of knowledge.

\section{The De-Westernisation and Islamisation of Contemporary Knowledge}

The concept of the de-Westernisation and Islamisation of present-day knowledge includes, the removal the un-Islamic, Western elements and concepts, and their experiments with key Islamic elements and concepts projecting the worldview, ethical framework and legal principles of Islam. Some of the key Islamic elements and concepts are those pertaining to religion (din), people (insan), knowledge ( $\mathrm{ilm}$ and ma'rifah), wisdom (hikmah), justice ('adl), and right action ('amal as adab). ${ }^{46}$

The basic ontological, epistemological, ethical and cultural differences between Islam and the dominant, secular West stem from the differences in their belief systems and cultural values. Western knowledge and science are based on the Western perception of God (or more accurately no-God) as which is different from the Islamic perception based on revealed knowledge. Western perceptions of the creation and the purpose of human beings are different from the Islamic worldview. Those Muslims who have profound faith and live in the modern Westernised and secularised milieu, have to struggle against Westernisation in order to achieve liberation. ${ }^{47}$

The Islamic perspective is based on a fixed and unchanging conception of revelation. The conception of God, of the nature of man, the psychology of the human soul, and the meaning of knowledge, happiness, virtues and vices, and of prophethood, have not changed during the long ages of the Islamic epoch. It is important for Muslims to be conscious of their worldview in order to construct their identity in relation to Westernisation.

Muslims have to acquire a deeper and more reflective understanding of the Islamic views on knowledge, rationalism and philosophy. They must also gain 
insight into history and civilisation. They have to be ready to face the intellectual and social challenges arising from the secular, Western worldview of modernity. In this view, liberation from Westernisation and secularisation means freedom from conspiracies hatched by the Western media and research. The main purpose of the de-Westernisation of academia is to reorient the intellectual work against Orientalism. Resilience againts foreign imposed categories of knowledge and ontology, ${ }^{48}$ known as kalàm al-jadìd/kalam al- 'asr (the Dialectics of the Age), constitutes the latest paradigm and pedagogical method for Muslim liberation movements today. ${ }^{49}$

\section{Conclusion}

Liberation generally signifies redemption, salvation and freedom. Liberation theology seeks salvation and deliverance from all forms of oppression, especially socio-political and economic injustice, under the instructions of the scriptures that were interpreted by the prophets and theologians, and in order to help marginalised people. Thus, scriptures exhort us to struggle for the welfare of human beings, to help them againts all sorts of injustice and inequality. Islamic liberation theology addresses all aspects of existence. These include not only the socio-political, economic and theological, but also the historical, religious, and cultural. The best sources of Islamic liberation theology are the Qur' an and the traditions of Muhammad. Both provide guidance to those who suffer in the world. They condemn ignorance, illiteracy, and injustice.

This paper has shown that, although the terms and theory of liberation theology have been derived from the modern Christian context, they have been employed and further developed by progressive Muslim thinkers and educators in the context of liberation from all sorts of socio-political, religious and cultural oppressions. These include, colonialism, neo-colonialism and Westernisation. In this regard, many progressive Muslim scholars have contributed original views and methods from their own socio-politico perspectives. The latest trend in this history of Muslim liberation theology viz. the new dialectical theology or kalam e jadid will go a long way towards addressing and guiding the contemporary world and future Muslim generations in their struggle to maintain and preserve their freedom as taught by the Qur'an.

The beginning of this article, I argued that though the twenty-first century is the age of globalisation, science and technology many human societies are stumbling into several kinds of crises. On the one hand, many human beings still face the distress of unemployment, poverty, starvation, malnourishment and homelessness. On the other, the world has also been suffering from inter and intra-religious extremism and ethno-religious nationalism. People want 
to be liberated from both torments. Now the time has come for reformers and progressive Muslims, especially theologians to re-work, re-interpret and re-look at the traditional and medieval exegesis of classical Islamic theology.

In light of the above discussion, the following recommendations are made for educators and policy makers in Muslim countries:

- To obtain liberation from poverty, injustice and inequality, theologians have to propagate a theology that is relevant to the current time; human liberation lies in helping out the poor from a sociological and not only a metaphysical perspective.

- The Monarchical practices of Muslim rulers cum religious leaders should be void of nationalism, tribal and communal practices. They are supposed to be free from the intoxication of the power. Their role should be like that of the model caliphs and other leaders, who gave rights and dignity to every individual, irrespective of colour, race, gender and religion; to help and serve the people, and to bring peace and justice to society.

- In addressing the challenges of the modern age, the fanatical approaches based on the superiority of one's race, faith and colour, are non-productive. Guidance derived from the teachings of the Quran, must play a central and critical role not only in creating harmony and religious coexistence but also in explaining that human and religious diversity is normal. There is an urgent need to develop religio-cultural understanding of Islam as a civilisational project. An apparatus should be provided to help obtain the maximum development of love, peace, harmony and tolerance.

- Concerning the epistemological and axiological issues raised here, Muslim academicians have already explicated the challenges perceived by the Westernisation of science in view of the new dialectical theology (kalam e jadid). De-Westernisation of academic culture is an integral part of a Muslim's epistemological liberation in the modern age.

\section{Notes}

* Abdul Rehman Kaloi is a Ph.D student who has currently defended his Ph.D at the College of Religious Studies, Mahidol University, Thailand. This article is part of his thesis. Email: abdrehman@usindh.edu.pk

1. Kenneth Surin, 'Liberation,' in Critical Terms for Religious Studies, ed. Mark C. Taylor (Chicago: The University of Chicago, 1998), 173.

2. Encyclopedia of Religion, $2^{\text {nd }}$ ed., s.v, 'Liberation.'

3. John Bowker, The Oxford Dictionary of World Religions (London: Oxford University Press, 1997) 577.

4. Ibid., 577. 
5. In the mid-1960s some theologians, most particularly Gustavo Gutierrez of Peru, began to formulate a liberation theology rooted in the prophetic tradition of the Bible and contemporary social analysis, communicating this vision to progressive networks of patrol leaders throughout Latin America. See Rosemary Radford Ruther, 'Catholism,' in The Hope of Liberation in World Religions, ed. De La Torre Miguel (Texas: Baylor University Press, 2008), 17.

6. Irfan A. Omar, 'Islam,' in The Hope of Religion in World Religions, ed. De La Torre Miguel (Texas: Baylor University Press, 2008), 102.

7. Ibid, 93-4.

8. Encyclopedia of Religion, $2^{\text {nd }}$ ed., s.v, 'Liberation.'

9. Gustavo Gutierrez, A theology of Liberation, History, Politics and Salvation (New York: Orbis Book,1971),1-2.

10. Christopher Rowland, Introduction: The Theology of Liberation, Publication details, 1999, 1-5.

11. Phillip Berryman, Liberation Theology: The Facts about the Revolutionary Movement in Latin America and Beyond (New York: Pantheon Book, 1987), 5-6.

12. E.A. Livingstone, Concise Dictionary of the Christian Church, Publication details, 2000, 341 .

13. Christopher Rowland, The Cambridge Companion to Liberation Theology (London: Cambridge University, 2007).

14. Leonardo Boff and Clodovis Boff, Salvation and Liberation: In a Search of Balance Between Faith and Politics (New York: Orbiss Book, 1984), 8.

15. Berryman, Liberation Theology, 5-6.

16. Rowland, Cambridge Companion to Liberation Theology.

17. Edward Craig, Routledge Encyclopedia of Philosophy. Available at https://www. rep.routledge.com/

18. Asghar Ali Engineer, Islam and Liberation Theology: Essays on Liberative Elements in Islam (New Delhi: Gyn Publishing House, 1990), 1-15.

19. Omar, 'Islam', 102.

20. Asghar Ali Engineer Engineer, Muhammad as a Liberator: Rational Approach to Islam (New Delhi: Sterling Publisher, 2001), 171-8.

21. Sayyed Mojtaba Musavilari, The Seal of The Prophet and His Message (Tehran: Islam Foundation of Islamic, 2008), 90.

22. John L. Esposito, Islam: The Straight Path (New York: Oxford University Press, 1991), 4-6.

23. Ibid.

24. Ibid, 9.

25. Omar, 'Islam,' 97.

26. Engineer, Islam and Liberation Theology, 11-12.

27. The Umayyad were the first Islamic dynasty founded in Syria, and ruled from 661 to $750 \mathrm{CE}$.

28. Engineer, 'Islam and Liberation Theology,' 13.

29. These include Asgharali, an Indian, and Fazlur Rahman, a Pakistani modernist, both progressive Muslim scholars.

30. Engineer, Islam and Liberation Theology, 13.

31. Ibid.

32. Ibid. 
33. Engineer (1939-2013) has been considered a progressive and critical Indian scholar, known among the prominent Muslim thinkers of Islamic liberation theology and interfaith dialogue.

34. Engineer, Muhammad as a Liberator, 21-30.

35. Maududi Abdul A' la Sayed, Four Basic Terms of the Quran, trans. Abu Asad (Lahore: Islamic Publication Academy Centre 1979), 3-5.

36. Omar, 'Islam,' 110.

37. Asgharali Engineer, The Prophet of Non-Violence: Spirit of Peace, Compassion, and Universality in Islam (New Delhi: Vitasta Publishing, 2011), 109-21.

38. See Nasir Nasrin and Daud Abdullah, The Universal Theology of Liberation: Views from Muslim History (London: Islamic Human Right Commision, 2011), $10-1$.

39. For example, the work of Chandra Muzaffar with the International Movement for a Just World in Malaysia and the efforts of Farid Esack with HIV-positive Muslims in South Africa, are examples of progressive Muslims who occupy themselves with activist approaches. See Omid Safi, 2003, 'What is progressive Islam?' I S I M N EWS L E T T E R 13 / D E C EMB E R 200 3, 48. Available at http://jsrforum.lib.virginia.edu/pdfs/SafiProgressive.pdf

40. Hamid Algar, On the Sociology of Islam (Berkeley: Mizan Press, 1979), 11-33.

41. Farid Esack, Qur'an, Liberation \& Pluralism: An Islamic Perspective of Interreligious Solidarity Against Corruption (London: Oxford, 1997), 82-3.

42. Ibid, 86-7.

43. Ibid, 83.

44. Ibid, 100-1.

45. Ibid, 107.

46. 'Islamization of Contemporary Knowledge and the Role of the University in the Context of De-Westernization and Decolonization,' p. 12., A Lecture delivered by Prof Dr Wan Mohd Nor Wan Daud Founder Director Center for Advanced Studies on Islam, Science and Civilization (CASIS) Universiti Teknologi Malaysia, 26 $6^{\text {th }}$ June 2013. Available at https://www.utm.my/casis/wp-content/ blogs.dir/415/files/2013/07/Professorial-Speech.pdf.

47. Ibid.

48. Antje Gluk, Media Conflict and Decmocratisation: Dewesternisation (London: University of Leeds, 2015), 1-28.

49. Ibid, 4. 